\title{
Perceptions on self-efficacy of students studying at secondary education in the TRNC on Internet security
}

\section{Percepciones sobre la auto-eficacia, de los estudiantes que estudian en la educación secundaria en la TRNC, en la seguridad de Internet}

\author{
Erinç Erçağ \\ Near East University, Cyprus \\ erinc.ercag@neu.edu.tr \\ Mehmet Karabulut \\ Near East University, Cyprus \\ mehmet.karabulut@neu.edu.tr
}

\begin{abstract}
This study has been undertaken to determine perceptions on self-efficacy of high school students in relation to internet usage. In this quantitative study, the sample consisted of 880 high school students studying in 30 high schools located within the borders of TRNC. General Survey method as a type of descriptive research method is used for this research. In accordance with the sample of this research, participants' self-efficacy perceptions on safe internet usage were examined in 4 dimensions. The first dimension of the research participants' self-efficacy on "Social Network (social media) Safety" is examined. According to statements and responses to the questionnaires, it has been determined that they are fully sufficient in "Social Network (social media) Safety"; whereas in the second and third dimensions of the research which are "Malicious Software" and "Web Safety and Social Engineering" the participants' sufficiency is found to be at a moderate level. In the last dimension of the research covering "Computer Safety" students found to have sufficient levels. As a result, students are found to have adequate security in the Social Networks they regularly use, whereas they are moderately competent in Web Security and Social Engineering. Main reason of this outcome is the fact that the students do not use the internet in full consciousness and correctly, thus the students should receive training on these matters.
\end{abstract}

Keywords: Safe Internet Usage, Self-Efficacy Perceptions, TRNC, Public Schools, IT security, students, internet safety

\section{Resumen}

Este estudio se ha llevado a cabo para determinar las percepciones sobre la autoeficacia de los estudiantes de secundaria en relación con el uso de Internet. En este estudio cuantitativo, la muestra consistió en 880 estudiantes de secundaria que estudian en 30 escuelas secundarias ubicadas dentro de los límites de la RTCN. Para esta investigación se utiliza el método de Encuesta General como un tipo de método descriptivo de investigación. De acuerdo con la muestra de esta investigación, las percepciones de autoeficacia de los participantes sobre el uso seguro de Internet se examinaron en 4 dimensiones. Se examina la primera dimensión de la autoeficacia de los participantes de la investigación en "Red social (medios sociales) de seguridad". De acuerdo con las declaraciones y respuestas a los cuestionarios, se ha determinado que son plenamente suficientes en la "Red Social (medios sociales) de Seguridad"; Mientras que en la segunda y tercera dimensiones de la investigación que son "Software Malintencionado" y "Seguridad Web e Ingeniería Social", la suficiencia de los participantes se encuentra en un nivel moderado. En la última dimensión de la investigación que abarca "Seguridad informática", los estudiantes encontraron niveles suficientes. Como resultado, se encuentra que los estudiantes tienen una seguridad adecuada en las Redes Sociales que usan regularmente, 
mientras que son moderadamente competentes en Seguridad Web e Ingeniería Social. La principal razón de este resultado es el hecho de que los estudiantes no utilizan Internet con plena conciencia y correctamente, por lo que los estudiantes deben recibir capacitación sobre estos temas.

Palabras clave: Uso seguro de Internet, Percepciones de autoeficacia, TRNC, Escuelas Públicas, seguridad de TI, estudiantes, seguridad en Internet

\section{INTRODUCTION}

When it comes to the 21 st century, it is seen that people are moving into a period of intensive use of information. This period is considered to be the period with the most innovation and development in Information Communication Technology (ICT). $21^{\text {st }}$ century is accepted as the information age by the society and scientists (İşman, 2011). Changes in the structure of internet technology during this period, unilateral communication provided by Web 1.0 is replaced by bilateral communication provided by Web 2.0 (Aghaei, Ali Nematbakhsh and Khosravi Farsani, 2012; Kırık, 2014).

With the continuous development and widespread use of Internet Technology, applications such as individual and institutional obtaining and transferring information, easily promoting things or following developments etc. have become effective in human life (Akgün and Topal, 2015). Internet is used effectively in different areas of human life. In addition to the role it has acquired in homes, work places, state services, military areas, health sector etc. internet also plays an important role in providing for innovative and permanent learning with e-books, blogs, online training tools used in the field of education (Bedir, 2012). With the increase of mobile devices for personal use social media usage has also increased (O'Keeffe and Clarke-Pearson, 2011).

When the results of a worldwide research undertaken by the firm We Are Social at the last quarter of 2016 are examined it is observed that 3,419 billion of 7, 395 billion world population are active internet users. 2015 data of the same research recoded 3,010 billion active internet users out of a 7,210 billion population (We Are Social, 2016). These values shouw us that there is a significant increase in the number of users worldwide.

According to Turkish Statistics Institution (TÜİK) data for 2016 Turkey's population is 78 million. Based on We Are Social report, 46.28 million (58\%) of this population are internet users, and 42 million (53\%) are active social media users (TUIK, 2016; We Are Social, 2016).

When the research on Cyprus is examined, the rate of internet usage in Greek Cypriot administration is found as 0.81 million according to We Are Social report. For North Cyprus, based on 2016 final quarter report of Information Technologies Communication Institution (BTHK) the number of users for fixed internet usage is 67 , 433. Another result from the same report represents the number of mobile internet users as 297,145 . This can be interpereted as an increase in mobile internet usage as a result of widespread smart phone usage (BTHK, 2016).

Despite ICT and internet are present in our lives and the rapid development of these have many beneficial effects on human life, the harmful effects are also significant enough. The possibility of usage in every field both individual and institutionally makes this technology an important tool for malicious people. (Akgün and Topal, 2015). As a

Perceptions on self-efficacy of students studying at secondary education in the TRNC on Internet security. Erinç Erçağ y Mehmet Karabulut 
result of unsafe and unconscious use of internet, users may experience a variety of negative content. For examining online threats easily, companies producing security software are reporting threatening situations they detect and publish the results in online environment. The purpose here is to determine security vulnerabilities and to reduce the harm to the minimum by informing users about them.

One of the great convenience of internet technology for users is sharing information. Though it is considered an advantage for conscious users it consists of many problems for unconscious users. Especially for child and young users, online security problems and issue of online information privacy are on the top of these problems (Johnson et. al, 2012). ICT and Internet usage are as significant among children as adults. Nowadays children begin to use internet at an early age and more than half of child users also obtain accounts in social media platforms (Karakuş et. al, 2014).

Social media environment can be defined as posing many threats for children. In the absence of awareness raising and supervision unwanted situations are likely to occur. Strong presence of child and young users in social networks is taken to be a factor in spread of these risk elements. According to results obtained from Çağlltay et. al (2011) $44 \%$ of children believe social environment to be safe whereas $40 \%$ know that social networks are not safe. In the same study, $16 \%$ stated that they have no opinion on this matter.

Children accessing illegal sexual or violent content websites, being involuntarily directed to other sites via ads, drug traffickers or pro terrorists using internet as propaganda channels as problems caused by lack of internet supervision also decrease internet safety both for teenagers and children (Çelen, Çelik and Seferoğlu, 2011).

It is also an important task for informatics teachers at schools to take measures against threatening elements in ICT field (Gökmen, 2014). As a result of intensive use of internet in our daily lives, it also brings security vulnerabilities. Fast widespread of internet use, provided the ground for increased risk elements in the online environment. Risk elements present in online environment generally target children. According to Aydın's study (2013) risks posed by internet are bullying, messages with sexual content, interaction with unknown people and misuse of personal information.

Based on 25,14 interviews conducted under EU Kids Online project with children between ages 9-16, Livingstone, Kirwil, Ponte and Staksrud (2013) have reached that $55 \%$ of children have come across with discomforting content in online environment. When findings of the study is detailed out, it is found that $58 \%$ of chilren defined as discomforting content to be pornography, violence, etc. Whereas $42 \%$ defined these as behavioral and contact based risks (viruses, agressive behaviour, unwanted messages, inappropriate images and messages).

While these offences are covered by cybercrime regulations around the World, it is thought that there is a serious problem with regards to internet safety since there is not many study on this matter as well as lack of any legislation in North Cyprus which could remedy possible grievances which may be experienced by internet users. As the result of the research carried out there is only one academic study within the boundaries of North Cyprus. This research is Erçağ's (2014) PhD Thesis titled "Effects of Virtual Learning Environments designed with an Authentic Learning Approach on Teachers' Success, Satisfaction and Self-Efficacy Perceptions". The fact that the said research was conducted on teachers working under Ministry of National Education and lack of

Perceptions on self-efficacy of students studying at secondary education in the TRNC on Internet security. Erinç Erçağ y Mehmet Karabulut 
any research focusing on students forces us to conclude that there is still a serious gap on this issue. Erçağ (2014), who clarifies and confirms this problem most clearly, emphasized throughout his work the need for awareness and the need to use internet safely. In his work Erçağ (2014) stated that the reason for opting for such a topic is the lack of legislative framework on cybercrime to remedy grievances of people vis-a-vis serious security problems in the country. Mowing onwards, it is stated by many studies that due to this lack individuals may experience a variety of problems. The lack of research in this area constitutes a major deficiency in our country, where the work on Information Security and the conscious use of the Internet is a crucial necessity.

Despite their intense use of internet, as mentioned by various sources cited above, the level of self-efficacy and perceptions of young internet users in North Cyprus is unknown. The main purpose of the study is to measure the level of self-efficacy and perceptions of young people at secondary education level in a country where no cybercrime legislation is in place.

At this stage the main question of this study is evaluation of self- efficacy in relation to internet usage of students studying in public schools in North Cyprus.

\section{Purpose of the Research}

The purpose of this research is to evaluate self-efficacy perceptions on safe internet usage of students studying at high schools governed by Vocational Technical Education Department and General Secondary Education Department of Ministry of National Education (MEB). For the research to achieve its targets within this context answers to sub-questions below will be sought.

- What is the level of perception and self-efficacy of students in relation to social network (social media) security?

- What is the level of perception and self-efficacy of students in relation to malicious software?

- What is the level of perception and self-efficacy of students in relation to web security and social engineering?

- What is the level of perception and self-efficacy of students in relation to computer security?

- What is the general level of students' safe internet usage in general?

- Is there a difference by gender in self-efficacy and perceptions of students in relation to safe internet usage?

\section{METHODOLOGY}

\section{Research Model}

This study used the survey model and the descriptive research method. Büyüköztürk et. al (2012) define survey model as "gathering of data for the purpose of defining specific characteristics of a given group".

Perceptions on self-efficacy of students studying at secondary education in the TRNC on Internet security. Erinç Erçağ y Mehmet Karabulut 


\section{Population and Sample}

Population of the research consists of students studying in high schools governed by Vocational Technical Education Department and General Secondary Education Department of TRNC Ministry of National Education during 2015-2016 academic year. Data with regards to distribution of students included in research population by schools is obtained from reports of relevant departments of Ministry of National Education and Culture.

Schools included in the research population have been stratified by region as Lefkoşa, Girne, Gazimağusa, Güzelyurt and İskele. Based on each strata the number of students for questionnaire purposes is determined. Table 1 shows the distribution and number of students calculated based on stratas.

Table 1. Distribution of Questionnaires by Strata

\begin{tabular}{llllll}
\hline & $\begin{array}{l}\text { Department } \\
\text { of Secondary } \\
\text { Education }\end{array}$ & $\begin{array}{l}\text { Number of } \\
\text { Questionnaires } \\
\text { by Province }\end{array}$ & $\begin{array}{l}\text { Number } \\
\text { of } \\
\text { Schools }\end{array}$ & $\begin{array}{l}\text { Number of } \\
\text { Questionnaires } \\
\text { by School }\end{array}$ & $\begin{array}{l}\text { Number of } \\
\text { Questionnaiers } \\
\text { by Class Level }\end{array}$ \\
\hline \multirow{2}{*}{ Lefkoşa } & GSE & 200 & 6 & 33 & 8 \\
& VTSE & 174 & 5 & 34 & 9 \\
Gazimağ & GSE & 123 & 4 & 31 & 8 \\
usa & VTSE & 71 & 3 & 24 & 6 \\
Girne & GSE & 86 & 3 & 28 & 7 \\
\multirow{2}{*}{ Güzelyu } & VTSE & - & - & - & - \\
rt & GSE & 67 & 3 & 22 & 6 \\
\multirow{2}{*}{ Iskele } & GTSE & 58 & 2 & 28 & 7 \\
\hline TOTAL & VTSE & 59 & 2 & 28 & 7 \\
\hline
\end{tabular}

"Self-efficacy and perception on Safe Internet Usage of Students studying at TRNC Public Schools" questionnaire was applied to schools governed by Secondary Education Department.

\section{Data Collection Tool}

For purposes of collecting demographic information a personal information form is added to the first section of the questionnaire. In section two, "Self-Efficacy Perceptions Scale on Students' Safe Internet Usage" developed by Çavuş and Erçağ (2014) is used to measure self-efficacy and perceptions with regards to safe internet usage. The Scale measures participants' self-efficacy on safe internet usage under four dimensions which are "Social Network Security (Social Media Security), "Malicious Software", "Web Security and Social Engineering" and "Computer Safety". The scale consists of 12 questions on social network security, 8 questions on malicious software, 9 questions on web security and social engineering and 6 questions on computer security.

Perceptions on self-efficacy of students studying at secondary education in the TRNC on Internet security. Erinç Erçağ y Mehmet Karabulut 
Cavus ve Ercag (2014) have calculated the Kaiser - Meyer - Olkin (KMO) sample coefficient for "Self-Efficacy Perceptions Scale on Students' Safe Internet Usage" as 0.89 . According to the results of analysis on the questionnaires validity and reliability, the reliability coefficient (alfa) is found as 0.981 .

\section{Data Analysis}

Information obtained from 880 students who participated in the questionnaire are transferred under an expert supervision into a database created by "Statistical Package for Social Science" (SPSS) 24 and statistical analysis is conducted. In the analysis of data obtained; Kruskal - Wallis (K-independent sample test) test analysis techniques were used to analyse the frequency (f), percentage (\%), arithmetic mean $(\bar{X})$, and standard deviation (SD), whether there are differences between independent variables or not and the results are tabulated for interpretation.

\section{FINDINGS}

\section{Demographic Information on Students Participating in the Research}

In this section frequency (f) and percentage (\%) values of gender, age, distribution by region of students are presented in table format.

\section{Distribution of Students by Secondary Education Department}

Research has taken place in high schools located in the TRNC. High schools function as governed by either General Secondary Education Department or Vocational Technical Secondary Education Department.

\section{Table 2. Distribution of Students by Secondary Education Department}

\begin{tabular}{lll}
\hline & $\boldsymbol{N}$ & $\mathbf{\%}$ \\
\hline General Secondary Education & 531 & 60,3 \\
Vocational Technical Education & 349 & 39,7 \\
\hline Total & 880 & 100,0 \\
\hline
\end{tabular}

As it can be seen in Table 2, 60.3\% $(\mathrm{N}=531)$ of students are under General Secondary Education whereas 39.7\% (N=349) of them are under Vocational Technical Secondary Education. This distribution shows that the participation of general secondary education schools were majority.

\section{Distribution by Gender}

Table 3 represents the distribution by gender of participating students.

Table 3. Distribution by Gender

\begin{tabular}{lcc}
\hline & $\boldsymbol{N}$ & $\boldsymbol{\%}$ \\
\hline Female & 516 & 58,6 \\
Male & 364 & 41,4 \\
\hline Total & 880 & 100,0 \\
\hline
\end{tabular}

Per Table $358,6 \%(N=516)$ of 880 participants were female and $41,4 \%(N$ $=364$ ) were male. Female students make up the majority of this sample.

Perceptions on self-efficacy of students studying at secondary education in the TRNC on Internet security. Erinç Erçağ y Mehmet Karabulut 


\section{Resulst regarding Self-Efficacy and Perceptions on Safe Internet Usage of High School Students}

Survey results showing self-efficacy and perceptions on safe internet usage of high school students will be examined under four dimensions.

Average Data on Factors in the Security Dimension in Social Networks. Mean $(\overline{\mathbf{X}})$ and Standard Deviation (SD) data for the expressions in the safety dimension of social networks, the first dimension of the "Self-efficacy for safe Internet usage of high school students" survey, are given in Table 4.

Table 4. Average Data on Security Dimension in Social Networks

Social Network Security (Social Media Security)

1. The information I share on social networks can be hidden from people I do not want.

2. Preventing requests from people I do not know / want on social networking networks

3. Can hide personal information from people I do not want on social networking networks

4. Protecting the information I share in terms of security threats on social networking networks

5. In case of stolen password in social networks, you can apply to relevant authorities

6. Sharing information on social networks that will not harm my personality, such as videos and photos

7. Share information on social networks that will not harm others' personalities

3,9352

4,3739

8. Safely use social networks like Facebook and Twitter

9 Can protected themselves from virus-infected videos shared on social networks

10. Taking measures against security vulnerabilities in social networks

$$
4,4943
$$

11. Prevent my photo albums from being stolen on social networks

12. Ability to create strong passwords on social networks

$$
4,3125
$$

Looking at Table 4, it is seen that the responses to the questions posed under the Social Network Security (Social media) dimension are above the average of 4.00, and

Perceptions on self-efficacy of students studying at secondary education in the TRNC on Internet security. Erinç Erçağ y Mehmet Karabulut 
they point to the Fully Qualified option according to the rating limits. Young people's belief in having sufficient consciousness to secure their security in social networks and to have trust in themselves in achieving this indicates that they have sufficient selfefficacy. However, the average point of responses given to statements given in Article 5 "In case of stolen password in social networks, you can apply to relevant authorities" $(\bar{X}=3,93, \mathrm{SD}=1.20)$, Article 9 "Can protect themselves from virus-infected videos shared on social networks" ( $\bar{X}=3,96, \mathrm{SD}=1.19)$, Article 10 "Taking measures against security vulnerabilities in social networks" $(\overline{\mathrm{X}}=3,94, \mathrm{SD}=1.14)$ and 11. Madde "Prevent my photo albums from being stolen on social networks" $(\overline{\mathrm{X}}=3,63, \mathrm{SD}=1.28)$ are lower than responses given to other statements. It can be stated that the general situation of participants is completely adequate in terms of security in Social Networks (Social Media).

Average results on Factors related to Malivious Software Dimension. Mean $(\overline{\mathbf{X}})$ and Standard Deviation (SD) of data related to statements on malicious software dimension of the "Self-efficacy for safe Internet usage of high school students" survey, are given in Table 5 .

Table 5. Average Data on Malicious Software Dimension

\begin{tabular}{|c|c|c|}
\hline Malicious Software & $\overline{\boldsymbol{X}}$ & SD \\
\hline 13. Prevent computer being infected with malicious software & 3,6182 & 1,22252 \\
\hline 14. Protect my passwords from Keylogger & 3,2091 & 1,34051 \\
\hline $\begin{array}{l}\text { 15. Cleaning malicious software when my computer is } \\
\text { infected }\end{array}$ & 3,5852 & 1,28597 \\
\hline $\begin{array}{l}\text { 16. Take security measures to prevent viruses from infecting } \\
\text { computers }\end{array}$ & 3,7636 & 1,22211 \\
\hline 17. Protection against Worms & 3,2420 & 1,31563 \\
\hline $\begin{array}{l}\text { 18. Taking security measures to prevent computer being } \\
\text { infected with Trojans }\end{array}$ & 3,1523 & 1,35405 \\
\hline 19. Protection against spyware & 3,2193 & 1,35618 \\
\hline 20. Can use Microsoft Security Essentials & 3,3989 & 1,34113 \\
\hline
\end{tabular}

Table 5 shows average results in relation to Malicious Software dimension. When Table 5 is viewed, it is seen that the average is below 4. Participants' responses to statements in Article 13 "Prevent computer being infected with malicious software" $(\bar{X}=3,61, \mathrm{SD}=1.22)$, Article 15 "Cleaning malicious software when my computer is infected" ( $\bar{X}=3,58, \mathrm{SD}=1.28)$ and Article 16 "Take security measures to prevent viruses from infecting computers" $(\bar{X}=3,76, \mathrm{SD}=1.22)$, represents "Adequate" option whereas the average responses to statements in Article14 "Protect my passwords from Keylogger" $(\bar{X}=3,20, \mathrm{SD}=1.34)$, Article 17 "Protection against Worms" $(\bar{X}=3,24$,

Perceptions on self-efficacy of students studying at secondary education in the TRNC on Internet security. Erinç Erçağ y Mehmet Karabulut 
$\mathrm{SD}=1.31$ ), Article 18 "Taking security measures to prevent computer being infected with Trojans" $(\bar{X}=3,15, \mathrm{SD}=1.35)$, Article 19 "Protection against spyware" $(\bar{X}=3,21$, $\mathrm{SD}=1.35)$ and Article 20 "Can use Microsoft Security Essentials" ( $\bar{X}=3,39, \mathrm{SD}=1.34)$ represents "Moderately Adequate" option in the rating system. It can be said that the users are not fully sufficient on malicious software, they lack information and for this reason they do not see themselves as fully adequate.

\section{Dimension \\ Average Data related to Factors in Web Security and Social Engineering}

Mean $(\overline{\mathbf{X}})$ and Standard Deviation (SD) of data related to statements on web security and social engineering dimension of the "Self-efficacy for safe Internet usage of high school students" survey, are given in Table 6 .

Table 6. Web Security and Social Engineering Dimension

\begin{tabular}{lcc}
\hline Web Security and Social Engineering & $\overline{\boldsymbol{X}}$ & SD \\
\hline 21. Safely shopping online & 3,5852 & 1,36326 \\
22. Taking measures agains spam mail & 3,7795 & 1,27692
\end{tabular}

23. Can be protected from social engineering equipment such as camcorders, camcorder glasses

$3,1386 \quad 1,36971$

24. Taking security measures during interactive banking transactions

$3,3136 \quad 1,34471$

25. Taking necessary measures for hoax e-mail

management

$3,3318 \quad 1,33437$

26. Protecting themselves from phishing

$3,4466 \quad 1,33368$

27. Can create a secret password

28. Can differentiate between HTTP and HTTPS

$4,1375 \quad 1,18981$

29. Can protec themselves from social engineering attacks through e-mail

$3,0477 \quad 1,40614$

$3,2761 \quad 1,34575$

It can be seen from Table 6 that responses given to statement in Article 21. "Safely shopping online" $(\bar{X}=3,58, \mathrm{SD}=1.36)$, Article 22 "Taking measures against spam mail" $(\bar{X}=3,77, \mathrm{SD}=1.27)$, Article 26 "Protecting themselves from phishing" $(\bar{X}=3,44, \mathrm{SD}=1.33)$ and Article 27 "Can create a secret password" $(\bar{X}=4,13, \mathrm{SD}=1.18)$ represents "Adequate". Based on the average results can be seen that the students do not have sufficient information. Level of adequacy in relation to Article 23 "Can be protected from social engineering equipment such as camcorders, camcorder glasses" $(\bar{X}=3,13, \mathrm{SD}=1.36)$, Article 24 " Taking security measures during interactive banking transactions " $(\bar{X}=3,31, \mathrm{SD}=1.34)$, Article 25 "Taking necessary measures for hoax email management" $(\bar{X}=3,33, \mathrm{SD}=1.33)$, Article 28 "Can differentiate between HTTP

Perceptions on self-efficacy of students studying at secondary education in the TRNC on Internet security. Erinç Erçağ y Mehmet Karabulut

Página 9 de 16 
and HTTPS" ( $\bar{X}=3,04, \mathrm{SD}=1.40)$ and Article 29 "Can protect themselves from social engineering attacks through e-mail" $(\bar{X}=3,27, \mathrm{SD}=1.34)$ have been found to be "Moderately Adequate".

\section{Average Data on Factors in Computer Safety Dimension}

Mean $(\overline{\mathbf{X}})$ and Standard Deviation (SD) of data related to statements on computer safety dimension which is the fourth and last dimension of the "Self-efficacy for safe Internet usage of high school students" survey, are given in Table 7.

Table 7. Average Data on Computer Safety Dimension

\begin{tabular}{lcr}
\hline Computer Safety & $\overline{\boldsymbol{X}}$ & SD \\
\hline 30. Can protect personal files & 4,3273 & 1,01398 \\
$\begin{array}{l}\text { 31. Can define a password to Windows OS } \\
\text { 32. Can take necessary measures for accessing the }\end{array}$ & 4,1318 & 1,12106 \\
computer & 4,1443 & 1,11392 \\
33. Can update security software when necessary & 4,0000 & 1,13482 \\
34. Can encrypt files & 3,9602 & 1,25008 \\
35. Can back up files periodically to prevent loss & 3,7818 & 1,29324 \\
\hline
\end{tabular}

When data in Table 7 is examined the students can be said to be at a good level. Students responded as "Fully Adequate" to statement in Article 30 "Can protect personal files" ( $\bar{X}=4,32, \mathrm{SD}=1.01)$. Based on responses given to Article 31 " Can define a password to Windows OS" $(\bar{X}=4,13, \mathrm{SD}=1.12)$, Article 32 "Can take necessary measures for accessing the computer" $(\bar{X}=4,14, \mathrm{SD}=1.11)$, Article 33 "Can update security software when necessary" $(\bar{X}=4,00, \mathrm{SD}=1.13)$, Article 34 "Can encrypt files" $(\bar{X}=3,96, \mathrm{SD}=1.25)$ ve Article 35 "Can back up files periodically to prevent loss" $(\bar{X}=3,78, \mathrm{SD}=1.29)$ it is seen that they think they are adequate in these matters but they do not consider themselves as fully adequate.

\section{Evaluating Students' Self-Efficacy in Social Network Security Dimension}

Table 8. Social Network Security

\begin{tabular}{cc|c|c}
\hline & $\mathbf{N}$ & $\overline{\boldsymbol{X}}$ & SD \\
\hline Social Network Security & 880 & 4,2246 &, 68755 \\
\hline
\end{tabular}

In Table 8 students' adequacy in Social Network Security dimension is examined. Responses of students participating in the research is determined as Fully Adequate $(\bar{X}=4,2246)$.

Perceptions on self-efficacy of students studying at secondary education in the TRNC on Internet security. Erinç Erçağ y Mehmet Karabulut 
Evaluating Students' Self-Efficacy on Safe Internet Usage in Malicious Software Dimension

Table 9. Malicious Software

\begin{tabular}{cc|c|c}
\hline & $\mathbf{N}$ & $\overline{\boldsymbol{X}}$ & SD \\
\hline Malicious Software & 880 & 3,3986 & 1,01785 \\
\hline
\end{tabular}

Table 9 shows that the average of responses given by students on malicious software brings forward "Moderately Adequate" option $(\bar{X}=3,39, \mathrm{SD}=1,01)$. Students having moderate level of adequacy about malicious software indicates that they are under risk while using information technologies. Lack of knowledge on malicious software shows that they are vulnerable to risk elements of cyber world. Students whose level of precautions is at a moderate level will be under risk in online and social media environments.

Çakır and Kesler, (2012) state that $41 \%$ of students at Anadolu University responded as limited knowledge when asked "What is the level of your knowledge on computer viruses?".

Evaluating Students' Self-Efficacy on Safe Internet Usage in Web Safety and Social Engineering Dimension

Table 10. Evaluation in Web Security and Social Engineering Dimension

\begin{tabular}{cccc}
\hline & $\mathbf{N}$ & $\overline{\boldsymbol{X}}$ & SD \\
\hline Web Security and Social Engineering & 880 & 3,4508 &, 94410 \\
\hline When Table 10 is looked at, it can be & observed that
\end{tabular}

When Table 10 is looked at, it can be observed that the level of students' response to questions on Web Security and Social Engineering is "Adequate" ( $\bar{X}=3,45$, $\mathrm{SD}=$,94).

\section{Evaluating Students' Self-Efficacy on Safe Internet Usage in Computer Safety Dimension}

Table 11. Evaluation in Computer Safety Dimension

\begin{tabular}{lccc}
\hline & $\mathbf{N}$ & $\overline{\boldsymbol{X}}$ & SD \\
\hline Computer Safety & 880 & 4,0576 &, 89156 \\
\hline
\end{tabular}

When Table 11 is looked at, it can be observed that the level of students' response to questions on Computer Safety is "Adequate", $(\bar{X}=4.05, \mathrm{SD}=, 89)$. Students not perceiving themselves as fully adequate should be considered an important issue.

\section{Conclusion and Discussion}

Results regarding students' self-efficacy and perception levels on social network (social media) security

As a result of the research, it has been determined that high school students in TRNC have a sufficient level of self-efficacy and perceptions on social networks security. This can be attributed to the fact that mobile technology is evolving so that

Perceptions on self-efficacy of students studying at secondary education in the TRNC on Internet security. Erinç Erçağ y Mehmet Karabulut 
social networking platforms can be accessed from anywhere. When the results of the research are examined, it has been determined that the participants have sufficient competence to take necessary security measures in social network usage. However, the survey found that the factors investigated under the social network security dimension users' competence levels were below the levels required.

It is important to be conscious that the necessary precautions should be taken when considering the hazards involved in social networks. In the study conducted by Y1ldırım and Varol (2013) on conscious use of social networks 30.1\% of respondents responded yes to question "Do you receive any messages which disturbs you or interferes with your personality rights on social network?". To the question "Did a link you clicked on social networks lead you to a page you do not want?" $74.5 \%$ of respondents responded as yes. In a study on social network security H. Çakır, Hava, Gülen and Özüdoğru (2015) found that teacher canditates participating in the study have a moderate awareness on general social network security. K. Yenilmez, Turgut, Anapa and Ersoy, (2012) found that students using a personal computer has higher selfefficacy beliefs than those who do not.

\section{software \\ Results regarding students' self-efficacy and perception levels on malicious}

As a result of the research, it is seen that participants' level of knowledge about the malicious software is moderately competent. Security is the most important problem for children and young people in internet usage. It is possible to take security measures only by being a conscious user. As a result of the research, it is seen that the students do not have sufficient knowledge about protection from viruses and other malware. This situation is far behind than what should have been today which is an age of intense technology use. The current situation of students can be interpereted to be the indicator of insufficient coverage of malicious software in information technology courses.

Akgün and Topal (2015) point out that in the study they were doing, students had a considerably low level of awareness of antivirus and malware prevention, and they point out to the lack of knowledge of students. Particularly, 50.5\% of the participants were not sure about their competence in finding and using software used to provide information security. In addition, they found that more than $60 \%$ of participants considered themselves to be concerned about the protection of personal information in social networking environments, while at the same time seeing themselves as sufficiently sensitive about making necessary arrangements for this purpose and making privacy and reliability adjustments.

\section{Results regarding students' self-efficacy and perception levels on web security and social engineering}

Internet users need to have sufficient knowledge and self-efficacy in order to ensure security in the internet environment and to take measures against social engineering attacks. As a result of the research on high school students it has been determined that participants are uncertain whether they are adequately knowledgeable in web security and social engineering.

Perceptions on self-efficacy of students studying at secondary education in the TRNC on Internet security. Erinç Erçağ y Mehmet Karabulut 
Kruger, Drevin, Flowerday and Steyn (2011) found that $47 \%$ of the participants did not know what social engineering and social engineering related concepts were. M Tekerek and Tekerek (2013) found that the students' competence in using secure passwords in the internet environment was low. In the study of Akgün and Topal (2015) $71.6 \%$ of participants stated that they had information about how to create a secure password.

\section{Results regarding students' self-efficacy and perception levels on computer safety}

As a result of the research, the students who participated in the research stated that they have sufficient knowledge on computer security with their responses to the statements they were asked. It can be said that participants may think they are adequate, but they are indecisive if they are fully qualified. Considering we are in an Information Technology era facts obtained in relation to computer safety do not satisfy the expectations. Nowadays children grow up with internet technology. It is expected that new generation users who can be defined as technology locals ((DeFranco, 2011) have high levels of knowledge on computer usage and safety.

Karaoğlan Y1lmaz et. al (2014) found that as a result of the mixed research conducted with 124 university students, the students did not have sufficient competence to ensure information security. They stated lack of sufficient training to be one of the main reason for this issue.

\section{Results regarding students' self-efficacy and perception levels on general safe internet usage}

In today's world where internet technology is widespread, users' knowledge level for secure internet usage is important for protectition from harmful aspects of the internet. As a result of the study in order to describe high school students' self-efficacy and perceptions of safe internet use in TRNC it has been determined that students have sufficient knowledge about social network security (social media security). However, web security and social engineering, malware and computer security are not completely adequate, but are found to be less than expected according to today's computing needs. The results of the research are similar to those of the researches (Gökmen and Akgün, 2016; Karaoğlan Y1lmaz et. al, 2014; Kruger et. al, 2011; Topal and Akgün, 2015). Durmuş and Başarmak (2014) found that internet usage periods are directly related to educational internet use. In the study, it was determined that educational self-efficacy levels of educational internet users were higher for those users using internet more than 8 hours.

\section{Results regarding students' self-efficacy and perception on safe internet usage by gender of participants}

When the analysis results were examined, it was determined that male students had a higher self-efficacy perception than the female students in all four dimensions evaluated within the scope of the research. In Gökmen and Akgün's research (2014) on candidate teachers for Computer and Instructural Technologies it is determined that

Perceptions on self-efficacy of students studying at secondary education in the TRNC on Internet security. Erinç Erçağ y Mehmet Karabulut 
male teacher candidates had higher knowledge levels on information technology security compared to female teacher candidates.

It is seen that the researches on the use of information technologies show differences according to gender. Beder and Ergun (2015) found that the level of consciousness of the female students was higher in the findings obtained in the study of middle school students. Findings are similar to findings of Eray Yılmaz, Şahin and Akbulut (2016). Findings are opposite to the findings of M Tekerek and Tekerek, (2013). The study found that girls were better than boys on information security. Another study was conducted by Timur et al. (2013) on computer self-efficacy. They found no significant difference between the participants' gender and computer use selfefficacy.

Presentation of the article: February 13, 2017

Date of approval: March 11, 2017

Date of publication: Juny 30, 2017

Erçăg, E., y Karabulut, M. (2017). Perceptions on self-efficacy of students studying at secondary education in the TRNC on Internet security. RED. Revista de Educación a Distancia, 54. Consultado el (dd/mm/aaaa) en http://www.um.es/ead/red/54/ercag_karabulut.pdf

FINANCIACIÓN

Esta investigación no ha recibido ninguna subvención específica de los organismos de financiación en los sectores públicos, comerciales o sin fines de lucro.

FUNDING

This research has received no funds from the public, commercial or non-profit funding agencies or bodies.

\section{References}

Aghaei, S., Ali Nematbakhsh, M., \& Khosravi Farsani, H. (2012). Evolution of the World Wide Web: From Web 1.0 to Web 4.0. International Journal of Web \& Semantic Technology, 3(1), 1-10. https://doi.org/10.5121/ijwest.2012.3101

Akgün, Ö. E., \& Topal, M. (2015). Information Security Awareness of the Senior Teacher Students: Sakarya University Sample. Sakarya University Journal of Education, 2(5), 98-121.

Beder, A., \& Ergun, E. (2015). Assessment Of Secondary School Students' Safe Internet Usage. Ĕ̌itim Bilimleri Ve Uygulama, 14(27), 23-41.

Bedir, U. (2012). Siber Alanda Güvenliğin "Technophobia” Üzerinden İnşası: Türkiye'de Güvenli Internet. Marmara Üniversitesi.

Bilgi Teknolojileri Ve Haberleşme Kurumu. (2015). 2015 Elektronik Haberleşme

Sektörü 3 Aylık Veriler Raporu. Retrieved July 29, 2016, from http://www.bthk.org/

Büyüköztürk, S., Akgün, O. E., Demirel, F., Karadeniz, S., \& Kılıç Çakmak, E. (2012).

Perceptions on self-efficacy of students studying at secondary education in the TRNC on Internet security. Erinç Erçağ y Mehmet Karabulut 
Bilimsel araştırma yöntemleri (19th ed.). Ankara: Pegem Akademi.

Çağıltay, K., Karakuş, T., Kurşun, E., \& Kaşıkc1, D. (2011). The Use Of Social Networks Among Children in Turkey. In EU Kids Online II Final ....

Çakır, H., Hava, K., Gülen, Ş. B., \& Özüdoğru, G. (2015). An investigation of preservice teachers' security awareness on social networking sites. International Journal of Human Sciences, 12(1), 887. https://doi.org/10.14687/ijhs.v12i1.3142

Çakır, S., \& Kesler, M. (2012). Threating the Security of Computer Viruses and Antivirus Software. In 14. Akademik Bilişim Konferansı (pp. 468-476). Retrieved November 12, 2016 from http://ab.org.tr/ab12/bildiri/82.pdf

Çavus, N., \& Ercağ, E. (2014). The scale for the self-efficacy and perceptions in the safe use of the Internet for teachers: The validity and reliability studies. British Journal of Educational Technology, 47(1), 76-90. https://doi.org/10.1111/bjet.12217

Çelen, F. K., Çelik, A., \& Seferoğlu, S. S. (2011). Children's Internet Usage and Online Risks They Face. In XIII. Akademik Bilişim Konferansı (pp. 645-652). İnönü Üniversitesi, Malatya. Retrieved October 20, 2016 from http://yunus.hacettepe.edu.tr/ sadi/yayin/AB11_Celen-Celik_Seferoglu_CocuklarInternet-Riskler.pdf

DeFranco, J. (2011). Teaching Internet Security, Safety in Our Classrooms. Techniques: Connecting Education and Careers (J1). Retrieved December 18, 2016 from http://eric.ed.gov/?id=EJ925444

Durmuş, A., \& Başarmak, U. (2014). Investigation of the Relation between Teacher Candidates Internet Self-Efficiency Belief and Their Problematic Intended Use. Ahi Evran Üniversitesi Kırşehir Ĕ̈itim Fakültesi Dergisi, 15(3), 49-67. Retrieved June $14,2016 \quad$ from http://dergipark.ulakbim.gov.tr/aeukefd/article/download/5000086779/5000080708

Erçağ, E. (2014). Effects of Virtual Learning Environments designed with Authentic Learning Approach on Teachers' Safe Internet Usage, Succes, Satisfaction and Self-Efficacy Perspectives. Near East University, Nicosia.

Gökmen, Ö. F. (2014). An Analysis Of Computer Education And Instructional Technology Student Teachers' Efficiacy To Teach Information Security.(Master Thesis), Department of Computer Education and Instructional Technology Sakarya Üniversitesi, Sakarya.

Gökmen, Ö. F., \& Akgün, Ö. E. (2014). An Analysis of Computer Education and Instructional Technology Student Teachers' Knowledge of Information Security according to Several Variables. Çukurova Üniversitesi Ĕ̈itim Fakültesi Dergisi, 44(1), 61-84. https://doi.org/10.14812/cufej.2015.004

Gökmen, Ö. F., \& Akgün, Ö. E. (2016). Teacher Candidates' Experiences of Cyber Crime and Their Views for the Information Security Course Content. Mustafa Kemal University Journal of Graduate School of Social Sciences, 13(33).

İşman, A. (2011). Uzaktan eğitim. Ankara: Pegem Akademi.

Perceptions on self-efficacy of students studying at secondary education in the TRNC on Internet security. Erinç Erçağ y Mehmet Karabulut

Página 15 de 16 
Johnson, J., Gupta, S., Carlson, L., Rifon, N. J., Larose, R., \& Quilliam, E. T. (2012). Adult and Teen Internet Safety Perceptions and Behaviors: a Comparative Protection Motivation Theory Examination. In American Marketing Association (pp. 138-140). In Ama Winter Educators' Conference Proceedings.

Karakuş, T., Çağıltay, K., Kaşıkcı, D., Kurşun, E., \& Ogan, C. (2014). Internet Habits and Safe Internet Use of Children in Turkey and Europe. Education and Science, 39(171).

Karaoğlan Yılmaz, G., Y1lmaz, R., \& Sezer, B. (2014). Secure Information and Communication Technology Usage Behavior of University Students and an Overview to Information Security Training. Bartin University Journal of Faculty of Education, 3(1), 176-176. https://doi.org/10.14686/BUEFAD.201416213

Kemp, S. (2016). Digital in 2016. Retrieved November 28, 2016 from http://wearesocial.com/uk/special-reports/digital-in-2016

Kırı, A. M. (2014). Place Of Internet In Family And Child Relationship: Qualitative Research. Journal of Research in Education and Teaching, 1(3). Retrieved October 12, 2016 from http://www.jret.org/FileUpload/ks281142/File/32.kirik.pdf

Kruger, H. A., Drevin, L., Flowerday, S., \& Steyn, T. (2011). An assessment of the role of cultural factors in information security awareness. In 2011 Information Security for South Africa (pp. 1-7). IEEE. https://doi.org/10.1109/ISSA.2011.6027505

O'Keeffe, G. S., \& Clarke-Pearson, K. (2011). The impact of social media on children, adolescents, and families. American Academy of Pediatrics, 127(4), 800-804. https://doi.org/10.1542/peds.2011-0054

Tekerek, M., \& Tekerek, A. (2013). A Research on Students' Information Security Awareness. Turkish Journal of Education, 2(3). Retrieved October 17, 2016 from http://dergipark.ulakbim.gov.tr/turje/article/viewFile/5000087519/5000081360

Timur, B., Y1lmaz, Ş., \& Timur, S. (2013). Pre-service Teachers' Self-efficacy Beliefs towards Computer Use. Mersin University Journal of the Faculty of Education, 9(1). https://doi.org/10.17860/EFD.88438

Topal, M., \& Akgün, Ö. E. (2015). Investigation Of Educational Internet Use SelfEfficacy Perceptions Of Prospective Teachers Enrolled At A Faculty Of Education: Sakarya University Sample. Kastamonu Education Journal, 23(1), 22.

Türkiye İstatistik Kurumu. (2016). HaneHalkı Bilişim Teknolojileri Kullanım Araştırması.

Yenilmez, K., Turgut, M., Anapa, P., \& Ersoy, M. (2012). Preservice Elementary Mathematics Teachers' Self-Efficacy Beliefs In Educational Internet Use. EJournal of New World Sciences Academy, 7(1).

Yıldırım, N., \& Varol, A. (2013). Security On Social Network: A Case Study Done At Bitlis Eren and Fırat Universities. Türkiye Bilişim Vakfi Bilgisayar Bilimleri Ve Mühendisliği Dergisi, 6(1(Bas111 7).

Y1lmaz, E., Şahin, Y. L., \& AKbulut, Y. (2016). Digital Data Security Awareness of Teachers. Sakarya University Journal of Education, 6(2), 26-45.

Perceptions on self-efficacy of students studying at secondary education in the TRNC on Internet security. Erinç Erçağ y Mehmet Karabulut 